\title{
Effects of Aging on Activities of Mitochondrial Electron Transport Chain Complexes and Oxidative Damage in Rat Heart
}

\author{
Z. TATARKOVÁ ${ }^{1}$, S. KUKA ${ }^{1}$, P. RAČAY ${ }^{1}$, J. LEHOTSKÝ ${ }^{1}$, D. DOBROTA ${ }^{1}$, D. MIŠTUNA ${ }^{2}$, \\ P. KAPLÁN ${ }^{1}$
}

${ }^{1}$ Department of Medical Biochemistry, Centre of Excellence for Cardiovascular Research of Slovak Academy of Sciences, Jessenius Faculty of Medicine, Comenius University, Martin, Slovak

Republic, ${ }^{2}$ Clinic of Surgery I, Jessenius Faculty of Medicine, Comenius University, Martin, Slovak Republic

Received April 15, 2010

Accepted September 10, 2010

On-line November 29, 2010

\begin{abstract}
Summary
Mitochondrial dysfunction and accumulation of oxidative damage have been implicated to be the major factors of aging. However, data on age-related changes in activities of mitochondrial electron transport chain (ETC) complexes remain controversial and molecular mechanisms responsible for ETC dysfunction are still largely unknown. In this study, we examined the effect of aging on activities of ETC complexes and oxidative damage to proteins and lipids in cardiac mitochondria from adult (6-month-old), old (15month-old) and senescent (26-month-old) rats. ETC complexes IIV displayed different extent of inhibition with age. The most significant decline occurred in complex IV activity, whereas complex II activity was unchanged in old rats and was only slightly reduced in senescent rats. Compared to adult, old and senescent rat hearts had significantly higher levels of malondialdehyde, 4hydroxynonenal (HNE) and dityrosine, while thiol group content was reduced. Despite marked increase in HNE content with age (25 and $76 \%$ for 15- and 26-month-old rats, respectively) Western blot analysis revealed only few HNE-protein adducts. The present study suggests that non-uniform decline in activities of ETC complexes is due, at least in part, to mitochondrial oxidative damage; however, lipid peroxidation products appear to have a limited impact on enzyme functions.
\end{abstract}

\section{Key words}

Aging • Heart • Mitochondria • Electron transport complexes • Oxidative damage

\section{Corresponding author}

P. Kaplán, Department of Medical Biochemistry, Jessenius Faculty of Medicine, Comenius University, Malá Hora 4, SK-036 01 Martin, Slovak Republic. Fax: +421-43-4136770. E-mail: kaplan@jfmed.uniba.sk

\section{Introduction}

The aging heart is characterized by many structural, physiological and biochemical changes. Numerous studies have suggested that age-associated deterioration in heart function can be related to oxidative damage by reactive oxygen species (ROS) produced during mitochondrial oxidative phosphorylation. Complex I and complex III of electron transport chain (ETC) have been recognized as two main sites for the generation of superoxide radical and subsequently other ROS (Barja 1999). As the major cellular source of ROS mitochondria are also the main target of their damaging effects (Endlicher et al. 2009). Age-related mutations of mitochondrial DNA, reduced mRNA expression and translation of genes coding for subunits of enzyme complexes were demonstrated in various tissues, including the heart (Mohamed et al. 2006, Preston et al. 2008). Besides the gene expression changes the posttranslational oxidative modifications of proteins appear to be a key mechanism of age-associated oxidative injury. Protein lesions, manifested as carbonylation, nitration or tyrosine derivatization were shown to accumulate in different tissues during aging (Leeuwenburgh et al. 1997, Kanski et al. 2005, Choksi and Papaconstantinou 2008). 
Protein lesions can result also from the formation of adducts with lipid peroxidation (LPO) products, such as malondialdehyde (MDA) and 4-hydroxynonenal (HNE) (Choksi and Papaconstantinou 2008, Yarian et al. 2006). Many studies have also shown that accumulation of oxidatively modified molecules is coupled to impairment in mitochondrial function. Declines in activities of the ETC complexes (Kumaran et al. 2004, Rodríguez et al. 2007) and enzymes of citric acid cycle (Kumaran et al. 2005, Yarian et al. 2006) as well as cytochrome c release from mitochondria (Phaneuf and Leeuwenburgh 2002) of aged heart have been demonstrated and proposed to contribute to dysfunction and death of cardiac myocytes. However, no consistent pattern of activity changes can be discerned. Enzymes were shown to be differentially affected and there are contradictory data on age-related changes of individual ETC complexes I-IV or citric acid cycle enzymes. Moreover, there are also studies showing modest or no changes in mitochondrial enzyme activities or oxidative damage in aged heart (Miró et al. 2000, Davies et al. 2001).

Therefore, the aim of this study was to examine the effect of aging on activities of ETC complexes in cardiac mitochondria. A subsequent aim was to evaluate the hypothesis that advancing age is associated with gradual accumulation of oxidative damage that contributes to mitochondrial dysfunction. We hypothesized that ROS-induced damage to mitochondria occurs via both LPO-mediated and direct modifications of mitochondrial proteins. To assess potential roles of these two mechanisms we have determined oxidative modifications of lipids and proteins in the rat heart during the aging process. The results obtained suggest that direct protein modification may play a more important role in age-associated decline in mitochondrial function than LPO.

\section{Materials and Methods}

\section{Animals}

Fifteen male Wistar rats (supplied by IEP SAS Dobra Voda, Slovakia) were divided into three groups (5 rats per group) according to age, as adult (6-monthold), old (15-month-old) and senescent (26-month-old). The animals were maintained as described previously (Kaplan et al. 2007a). All experiments were performed in accordance with the "Guide for the Care and Use of Laboratory Animals" published by The US National Institute of Health (NIH publication NO 85-23, revised
1996), and the ethical guidelines of the Jessenius Faculty of Medicine.

\section{Isolation of cardiac mitochondria}

The animals were sacrificed by decapitation after anesthetization by halothane. After cannulation of the aorta the hearts were immediately washed with physiological solution and stored at $-80{ }^{\circ} \mathrm{C}$ until used. Frozen powdered tissue of the whole heart (about $1 \mathrm{~g}$ ) was thawed in 10 volumes of ice-cold homogenization buffer $\left(30 \mathrm{mM} \mathrm{KH_{2 }} \mathrm{PO}_{4}, 5 \mathrm{mM}\right.$ EDTA, $0.3 \mathrm{M}$ sucrose, $\mathrm{pH}$ 7.0) with $0.3 \mathrm{mM}$ phenylmethylsulfonyl fluoride (PMSF) and homogenized in Potter-Elvehjem homogenizer. Cardiac mitochondrial fraction was isolated from individual tissue homogenates by differential centrifugation as previously described (Babusikova et al. 2004).

Determination of enzyme activities

Complex I (NADH-ubiquinone oxidoreductase)

The oxidation of NADH by complex I was recorded using the ubiquinone analogue decylubiquinone as electron acceptor (Nulton-Persson and Szweda 2001). The basic assay medium ( $35 \mathrm{mM} \mathrm{KH} \mathrm{PO}_{4}, 5 \mathrm{mM} \mathrm{MgCl}$, and $2 \mathrm{mM} \mathrm{KCN}, \mathrm{pH}$ 7.2) was supplemented with $5 \mu \mathrm{M}$ antimycin A, $60 \mu \mathrm{M}$ decylubiquinone and $0.1 \mathrm{mM}$ $\mathrm{NADH}$ in final volume of $1 \mathrm{ml}$. The enzyme activity was measured by starting the reaction with $50 \mu \mathrm{g}$ of mitochondrial protein at $30{ }^{\circ} \mathrm{C}$. The decrease in absorption due to NADH oxidation was measured at $340 \mathrm{~nm}$ using molar absorption coefficient $\varepsilon=6.2 \mathrm{mM}^{-1} \mathrm{~cm}^{-1}$.

Complex II (succinate-ubiquinone oxidoreductase or succinate dehydrogenase, SDH)

Succinate dehydrogenase activity was measured according to Powell and Jackson (2003) as the rate of 2,6-dichlorophenolindophenol (DCIP) reduction at $600 \mathrm{~nm}\left(\varepsilon=21 \mathrm{mM}^{-1} \mathrm{~cm}^{-1}\right)$ upon addition of $0.2 \mathrm{M}$ $\mathrm{KH}_{2} \mathrm{PO}_{4}$ (pH 7.6), $0.1 \mathrm{M} \mathrm{NaCN}, 0.02 \mathrm{M}$ phenazine methosulfate, $0.5 \mathrm{M}$ succinate and $1 \mathrm{mM}$ DCIP to mitochondria $(0.15 \mathrm{mg}$ protein per $\mathrm{ml}$ ) incubated at $30{ }^{\circ} \mathrm{C}$

\section{Complex III (ubiquinol-cytochrome c reductase)}

Activity of cytochrome c reductase was determined as the rate of antimycin A-dependent reduction of cytochrome $\mathrm{c}$ at $550 \mathrm{~nm}\left(\varepsilon=18.5 \mathrm{mM}^{-1} \mathrm{~cm}^{-1}\right)$ (Nulton-Persson and Szweda 2001). Mitochondria 
$(0.05 \mathrm{mg}$ protein per $\mathrm{ml})$ were incubated at $30{ }^{\circ} \mathrm{C}$ in

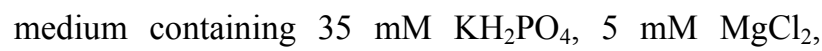
$2 \mathrm{mM} \mathrm{KCN}$ and $0.05 \%$ Triton X-100, pH 7.2 and reaction was started with $60 \mu \mathrm{M}$ reduced decylubiquinone and $50 \mu \mathrm{M}$ of cytochrome c.

\section{Complex IV (cytochrome c oxidase, COX)}

Activity of cytochrome c oxidase was determined spectrophotometrically by monitoring the rate of cytochrome c oxidation at $550 \mathrm{~nm}\left(\varepsilon=19.6 \mathrm{mM}^{-1} \mathrm{~cm}^{-1}\right)$ as previously described (Racay et al. 2009). Mitochondria (0.05 mg protein per $\mathrm{ml}$ ) were incubated at $30{ }^{\circ} \mathrm{C}$ in medium containing $50 \mathrm{mM}$ Tris- $\mathrm{HCl}(\mathrm{pH} 8.0), 0.01 \%$ $(\mathrm{w} / \mathrm{v}) \mathrm{n}$-dodecyl $\beta$-D-maltoside and reaction started with $5 \mu \mathrm{M}$ of reduced cytochrome c.

\section{Citrate synthase}

Citrate synthase activity was measured spectrophotometrically by monitoring formation of CoA$\mathrm{SH}$ with 2,2-dithiobisnitrobenzoic acid (DTNB). Mitochondria $(0.04 \mathrm{mg}$ protein per $\mathrm{ml}$ ) were incubated at $25^{\circ} \mathrm{C}$ in assay buffer containing $0.3 \mathrm{mM}$ acetyl CoA and $0.1 \mathrm{mM}$ 2,2-dithiobisnitrobenzoic acid (DTNB). The reaction was started by the addition of $0.5 \mathrm{mM}$ oxaloacatate and reduction of DTNB was followed at $412 \mathrm{~nm}\left(\varepsilon=13.6 \mathrm{mM}^{-1} \mathrm{~cm}^{-1}\right)$.

\section{Western blot analysis}

For detection of HNE-modified proteins the tissue homogenates (aliquots of $20 \mu \mathrm{g}$ proteins) were separated on $10 \%$ SDS-polyacrylamide gels under denaturing conditions and then transferred to nitrocellulose membranes using Mini Trans-Blot cell. Membranes were blocked in $5 \%$ milk with Tris-buffered saline Tween-20 (TBS-T) overnight and incubated with monoclonal antiHNE (Oxis International Inc.) for $90 \mathrm{~min}$. They were then washed with TBS-T, incubated with biotinylated antimouse secondary antibody (Vector, 1:10 000) for $90 \mathrm{~min}$, washed with TBS-T and incubated for 30 min with $\mathrm{ABC}$ (Vector, 1:1000). After last washing with TBS-T, immunoreactive proteins were visualized using the enhanced chemiluminescence reagent (Amersham) and quantified using NIH image software.

\section{Lipid peroxidation}

Conjugated diene formation was estimated from the absorbance ratio $\mathrm{A}_{233 \mathrm{~nm}} / \mathrm{A}_{215 \mathrm{~nm}}$ of mitochondria $(20 \mu \mathrm{g} / \mathrm{ml})$ dispensed in $10 \mathrm{mM}$ phosphate buffer containing $1 \%$ Lubrol (Kaplan et al. 2003).
Levels of LPO products, malondialdehyde and 4-hydroxynonenal, were measured according to LPO-586 Kit (Oxis International) in heart tissue homogenates.

\section{Total thiol group content}

Total thiol group content in cardiac mitochondria (aliquots of $0.15 \mathrm{mg}$ proteins) was determined spectrophotometrically as described previously (Sivoňová et al. 2007). Samples were incubated in medium containing $30 \mathrm{mM}$ imidazole (pH 7.4), 5 mM EDTA, 0.4 mM 2,2-dithiobisnitrobenzoic acid (DTNB). After $10 \mathrm{~min}$ incubation at room temperature the sample absorbance at $412 \mathrm{~nm}$ was measured together with the absorbance of reagent blank. The thiol group content was calculated using molar absorption coefficient $\varepsilon=13,600 \mathrm{M}^{-1} \mathrm{~cm}^{-1}$.

\section{Fluorescence studies}

All fluorescence measurements were performed in solution containing $50 \mu \mathrm{g}$ of mitochondrial protein per $\mathrm{ml}, 10 \mathrm{mM}$ HEPES and $100 \mathrm{mM} \mathrm{KCl}, \mathrm{pH}=7.0$ at room temperature on Shimadzu RF-540 spectrophotofluorimeter as shown previously (Kaplan et al. 2003). Emission spectra of dityrosine, a product of tyrosine oxidation, were recorded in range 380-440 nm (5 nm slit width) at excitation wavelength $325 \mathrm{~nm}(5 \mathrm{~nm})$. Emission spectra (425-480 nm) of lysine conjugates with LPO-end products were recorded after excitation at $365 \mathrm{~nm}(5 \mathrm{~nm})$. Binding of fluorescent probe 1-anilino-8naphtalenesulfonate (ANS) to mitochondrial membranes was measured following $10 \mathrm{~min}$ incubation of samples with the probe at $480 \mathrm{~nm}(5 \mathrm{~nm})$ with excitation at $365 \mathrm{~nm}(5 \mathrm{~nm})$.

\section{Statistical analysis}

Data are expressed as arithmetic means \pm S.E.M. One-way analysis of variance with post-hoc comparisons by Student-Neuman-Keuls test was carried out to test for differences among groups. A value of $\mathrm{p}<0.05$ was considered to be statistically significant.

\section{Results}

\section{Body weight and heart weight}

The effects of aging on body and heart weights are shown in Table 1. Both, body and heart weights of aged rats were significantly greater then those of adult rats. However, heart weight-to-body weight ratio, an indicator of cardiac hypertrophy, was unchanged. 
Table 1. Effect of aging on body weight, heart weight and heart to body weight ratio.

\begin{tabular}{lccc}
\hline & $\begin{array}{c}\text { Body } \\
\text { weight } \\
\text { (g) }\end{array}$ & $\begin{array}{c}\text { Heart } \\
\text { weight } \\
\text { (g) }\end{array}$ & $\begin{array}{c}\text { Heart/body } \\
\text { weight } \\
\text { (mg/g) }\end{array}$ \\
\hline 6-months old & $352 \pm 18.9$ & $1.06 \pm 0.08$ & $3.02 \pm 0.30$ \\
15-months old & $435 \pm 20.6^{* * *}$ & $1.25 \pm 0.10^{* *}$ & $2.88 \pm 0.31$ \\
26-months old & $435 \pm 27.9^{* * *}$ & $1.31 \pm 0.10^{* *}$ & $3.02 \pm 0.43$ \\
\hline
\end{tabular}

Values are expressed as means \pm S.E.M. of 5 experiments. ${ }^{* *} \mathrm{P}<0.01$, ${ }^{* * *} \mathrm{P}<0.001$; significantly different as compared to 6-months old rats.

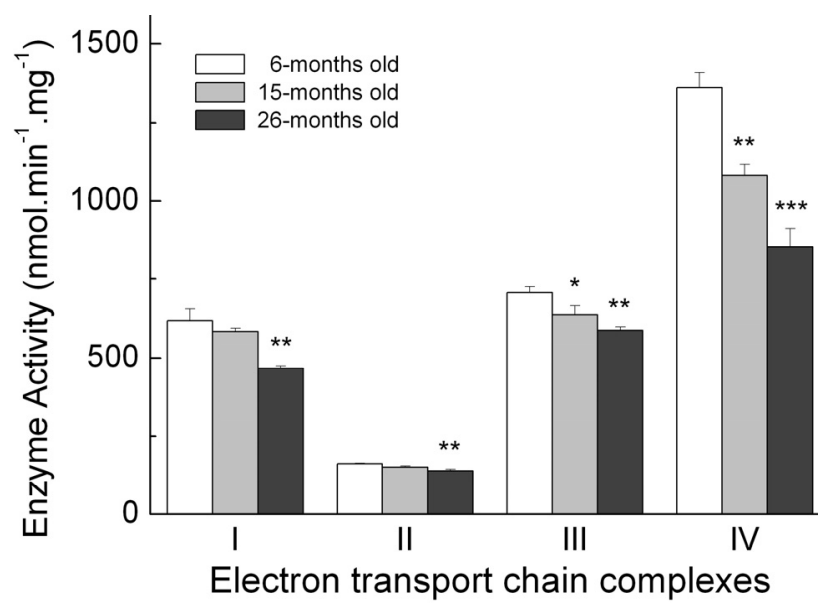

Fig. 1. Effect of aging on activities of ETC complexes in rat cardiac mitochondria. Values are given as mean \pm S.E.M. of 5 experiments. ${ }^{*} \mathrm{P}<0.05,{ }^{* *} \mathrm{P}<0.01,{ }^{* * *} \mathrm{P}<0.001$; significantly different as compared to 6 -months old rats.

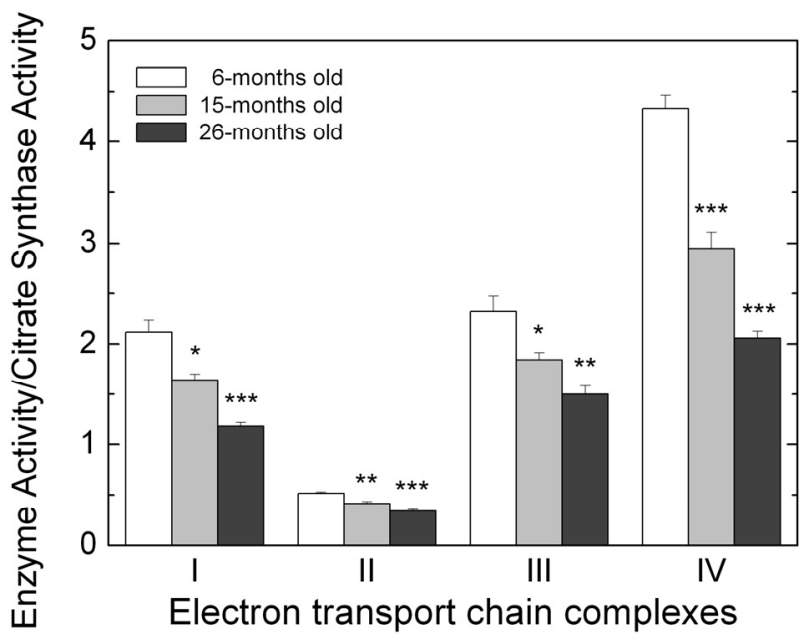

Fig. 2. Effect of aging on activities of ETC complexes related to citrate synthase activity. Values are given as mean \pm S.E.M. of 5 experiments. ${ }^{*} \mathrm{P}<0.05,{ }^{* *} \mathrm{P}<0.01,{ }^{* * *} \mathrm{P}<0.001$; significantly different as compared to 6 -months old rats.
Age-related changes in activities of electron transport chain complexes

To evaluate the effect of aging on mitochondrial function we measured enzyme activities of complexes I-IV in cardiac mitochondria isolated from adult (6-month old), old (15-month old) and senescent (26-month old) rats (Fig. 1). There were no significant difference in rotenone-sensitive complex I activities between adult and old rats, but the activity of senescent rats decreased to $76 \pm 1 \%$ of adult $(\mathrm{p}<0.01)$. Also complex II activity was significantly changed only in senescent rats, however, the decrease was less pronounced (to $86 \pm 3 \%$ of adult, $\mathrm{p}<0.01$ ) than that of complex I. On the other hand, antimycin A-sensitive complex III activity decreased significantly in both old (to $90 \pm 4 \%$ of adult, $\mathrm{p}<0.05$ ) and senescent rats (to $83 \pm 2 \%$ of adult, $\mathrm{p}<0.01$ ). The most pronounced age-related changes were observed in $\mathrm{KCN}$ sensitive complex IV (COX) activity, comparing to adult the activity decreased to $79 \pm 3 \%(\mathrm{p}<0.01)$ in old and $63 \pm 4 \% \quad(p<0.001)$ in senescent rat heart. To avoid possible effects of different yield or stability of mitochondria on aging activities of complexes were normalized relative to citrate synthase activity (Davies et al. 2001). The age-related changes in normalized activities were qualitatively similar to those of absolute activities but were more pronounced (Fig. 2) since citrate synthase activity progressively increased with age (6-month old 309 \pm 10 , 15-month old $364 \pm 13$ and 26 -month old $403 \pm 13 \mathrm{nmol} / \mathrm{min} / \mathrm{mg}$ protein). In contrast to absolute values, normalized activities of complexes I and II in old rats were significantly lower than those of adult rats.

\section{Mitochondrial oxidative damage during aging}

To assess if oxidative stress contributes to inhibition of enzyme activities the thiol group content and dityrosine fluorescence were measured as markers of protein oxidative damage. As shown in Figure 3, total thiol group content decreased by $20 \pm 1 \%(\mathrm{p}<0.001)$ at the age of 15 months and by $30 \pm 1 \%(p<0.001)$ at the age of 26 months. Aging significantly affected also protein dityrosine levels; compared with adult rats the level increased by $23 \pm 2 \%$ at 15 months and by $29 \pm 1 \%$ at 26 months (Fig. 3). These lesions were not accompanied by structural changes of proteins and/or membrane surfaces, since the binding of ANS probe was not significantly altered by aging (Table 2 ).

Effect of aging on lipid peroxidation was assessed by measurements of conjugated dienes and LPO 
Table 2. Effect of aging on lipid peroxidation and binding of ANS probe.

\begin{tabular}{cccc}
\hline & $\begin{array}{c}\text { Conjugated } \\
\text { dienes }\end{array}$ & \multicolumn{2}{c}{$\begin{array}{c}\text { Fluorescence } \\
\text { intensity of }\end{array}$} \\
\hline & $\mathrm{A}_{233 \mathrm{~nm}} / \mathrm{A}_{215 \mathrm{~nm}}$ & Lys-LPO & ANS \\
6-months old & $0.290 \pm 0.005$ & $30.3 \pm 1.2$ & $40.7 \pm 1.8$ \\
15-months old & $0.346 \pm 0.005^{* *}$ & $39.1 \pm 0.9^{* * *}$ & $37.9 \pm 1.3$ \\
26-months old & $0.448 \pm 0.003^{* * *}$ & $54.3 \pm 2.5^{* * *}$ & $43.9 \pm 2.5$ \\
\hline
\end{tabular}

Values are expressed as means \pm S.E.M. of 5 experiments. $* * \mathrm{P}<0.01, * * * \mathrm{P}<0.001$; significantly different as compared to 6-months old rats.

end-products. All parameters increased progressively with age (Table 2, Fig. 4). Compared to adult rats, MDA level increased by $13 \pm 7 \%(\mathrm{NS})$ and $30 \pm 4 \%(\mathrm{p}<0.05)$ at the age of 15 and 26 months, respectively (Fig. 4). HNE level increased by $25 \pm 7 \%(\mathrm{p}<0.01)$ at 15 months and further increased by $76 \pm 3 \%(p<0.001)$ in 26 -month old rats (Fig. 4). To see if accumulation of reactive aldehydes results in protein modification we measured fluorescence spectra corresponding to conjugates of LPO products with amino groups of proteins. As shown in Table 2, fluorescent products also significantly increased with aging. To further unravel the contribution of LPO to protein modifications, formation of HNE-protein adducts was investigated by Western blot analysis. Using specific anti-HNE antibodies we detected three bands with HNEmodified proteins (Fig. 5A). Densitometric analysis of Western blots suggests that these proteins exhibit different pattern of age-dependent changes (Fig. 5C). While protein(s) with molecular weight $\sim 57 \mathrm{kDa}$ showed progressive formation of $\mathrm{HNE}$ adducts with age, HNE modifications of low molecular weight proteins $(19-23 \mathrm{kDa})$ culminated at the age of 15 months. To control a loading error, $\beta$-actin was used as an internal control. There were no differences in content of this housekeeping-gene coded protein among adult, old and senescent rat hearts (Fig. 5B), suggesting that Western blot analysis of HNE-protein adducts was not affected by experimental errors.

\section{Discussion}

Results of this study demonstrate that cardiovascular aging is associated with accumulation of oxidative damage to lipids and proteins and progressive decline in activities of mitochondrial enzymes. However,

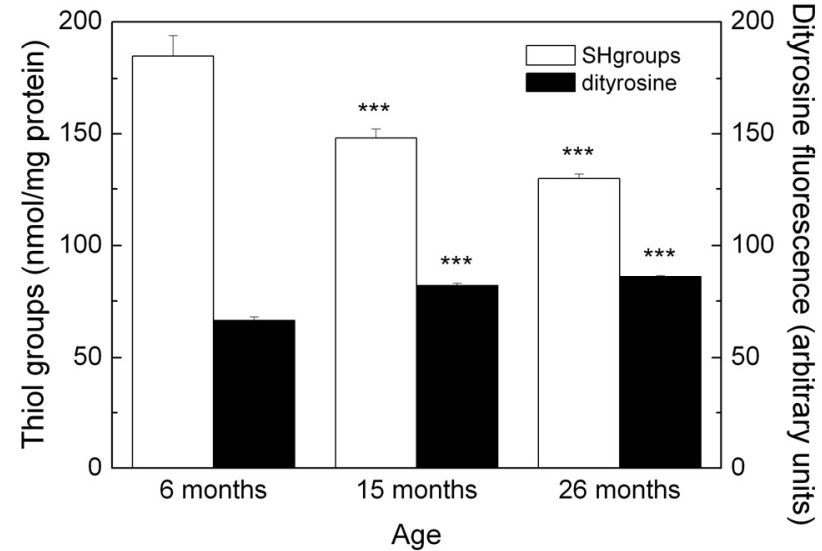

Fig. 3. Effect of aging on thiol group content and dityrosines in cardiac mitochondria. Values are given as mean \pm S.E.M. of 5 experiments. ${ }^{*} \mathrm{P}<0.05,{ }^{* *} \mathrm{P}<0.01,{ }^{* * *} \mathrm{P}<0.001$; significantly different as compared to 6 -months old rats.

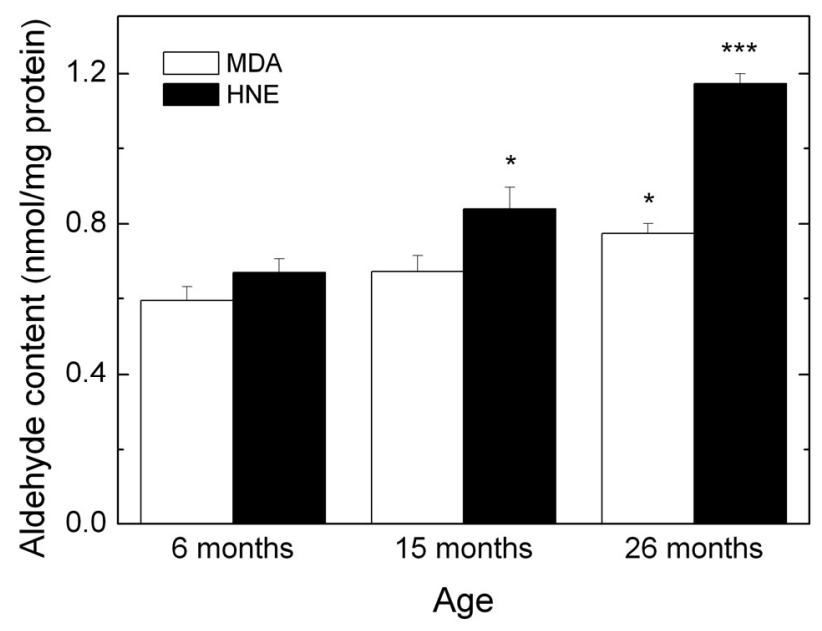

Fig. 4. Aging-associated changes in MDA and HNE contents in rat heart homogenates. Values are given as mean \pm S.E.M. of 4 experiments. ${ }^{*} \mathrm{P}<0.05$, ${ }^{* * *} \mathrm{P}<0.001$; significantly different as compared to 6-months old rats.

the extent of inhibition of individual enzymes was different. While there were relatively small age-related changes in complex II and III activities the decline in complex IV activity was twice as big as those of complexes II and III.

Effect of aging on mitochondrial enzymes in rodent hearts was examined in a number of studies, but with contradictory findings. For example, $42-46 \%$ reduction in complex I activity was demonstrated in hearts of 24-month-old rats (Kumaran et al. 2004, Preston et al. 2008), whereas other studies have reported no agerelated decrease in activity (Davies et al. 2001, Cocco et al. 2005). Our results are in agreement with recent study, which showed small but significant $\sim 9 \%$ decrease in activity of 12-14- and $\sim 13 \%$ decrease in 20-22-month 
A

\section{$\sim 57 \mathrm{kDa}$ \\ $\sim 23 \mathrm{kDa}$ \\ $\sim 19 \mathrm{kDa}$}

B

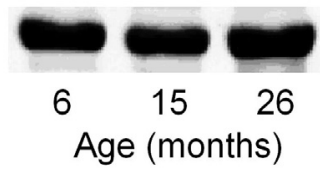

C

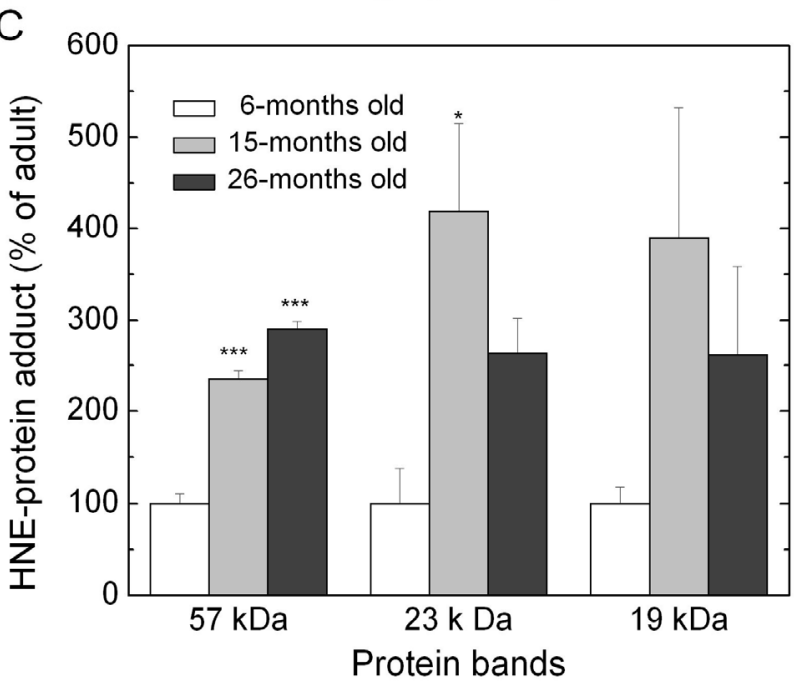

Fig. 5. Aging-associated changes in HNE-modified proteins in rat heart homogenates. Representative Western blot of HNE-protein adducts (A), actin (B) and HNE-modified protein contents expressed as a percentage of the average value in 6-months old rats (C). For detection of HNE-modified proteins $20 \mu \mathrm{g}$ proteins were applied on SDS-polyacrylamide gels Values are given as mean \pm S.E.M. of 3 experiments. ${ }^{*} \mathrm{P}<0.05$, ${ }^{* * *} \mathrm{P}<0.001$; significantly different as compared to 6 -months old rats.

old mouse heart mitochondria (Choksi and Papaconstantinou 2008). Surprisingly, literature data on complex II show declined (Kumaran et al. 2004, Cocco et al. 2005) unchanged (Preston et al. 2008) and also increased (Kwong and Sohal 2000, Davies et al. 2001, Choksi and Papaconstantinou 2008) activity in aged hearts.

Activities of complexes III and IV have been also shown to decline (Kwong and Sohal 2000, Kumaran et al. 2004), remain unchanged or increased (Davies et al. 2001, Cocco et al. 2005, Choksi and Papaconstantinou 2008) during aging. Our data are similar to those reported by Kumaran et al. (2004) who also showed agedependent decrease in all activities, although the pattern and extent of inhibition was different. To avoid speciesand tissue-specific changes we compared our results only to literature data on rodent hearts. Therefore, inconsistencies among the studies can be mainly due to differences in the experimental approaches such as mitochondrial populations or electron donors/acceptors used for measurements of complex activities (Fannin et al. 1999, Kwong and Sohal 2000) and differences in aging groups. In some studies (Davies et al. 2001, Cocco et al. 2005) the aged groups (24-28 months) were compared to young rats (aged 2-3 months). This may lead to underestimation of the observed aging effect, since activities of ETC complexes in hearts from young rats might be lower than those observed in adult 6-month-old rats. In our study, cardiac mitochondria were isolated from rats anesthetized with $2 \%$ halothane, a known inhibitor of ETC complexes (Hanley et al. 2002). However, this mechanism most likely did not affect our findings since this volatile anesthetic was eliminated during heart perfusion and isolation of mitochondria. Regardless of the contradictory data on activity changes of individual ETC complexes, majority of studies demonstrates some age-related impairment in ETC. Such non uniform inhibition of ETC complexes can result in altered electron flow through the chain, impaired ATP production and finally in altered cardiomyocyte function during aging.

In addition to altered energy transduction, imbalance among ETC complexes may cause increased electron leakage from ETC and oxidative stress. Under normal conditions, ETC produces low levels of ROS, which are eliminated by scavenging mechanisms so that no substantial oxidative damage occurs. ROS, elevated due to imbalance in ETC, can attack molecules near the sites of their generation, thus strengthening ETC dysfunction. Accumulation of oxidative damage during aging observed in our study demonstrates that oxidative stress has indeed occurred in mitochondria. Mitochondria isolated from old and senescent rats showed lower thiol group and increased dityrosine contents, indicating agerelated modifications of mitochondrial proteins. These results are consistent with previously reported data showing age-related changes in protein dityrosine, nitrotyrosine, carbonyl and thiol group content (Leeuwenburgh et al. 1997, Babusikova et al. 2004, Cocco et al. 2005, Choksi and Papaconstantinou 2008) and differs from those showing no protein oxidative damage in heart mitochondria (Davies et al. 2001). Function of ETC complexes depends also on structural 
integrity of membrane lipid bilayer. Increases in three biomarkers of LPO, conjugated dienes, MDA and HNE, in 15- and 26-month old rats indicate that aging is associated with significant lipid oxidative damage. Although elevated lipid peroxidation in myocardial aging has been demonstrated in several studies (Cocco et al. 2005, Judge et al. 2005), the consequences of this process are not clear, since several studies have failed to show correlation between LPO and inhibition of ETC complexes (Zhang et al. 1990, Miró et al. 2000). We have not tested the role of LPO in detail but unchanged binding of ANS probe to mitochondria suggest that aging is not accompanied with substantial conformational changes in membranes. Although generalized LPO appears not to be involved in functional derangement of mitochondria, processes, such as peroxidation of specific membrane lipid components (Lesnefsky and Hoppel 2008, Petrosillo et al. 2009) or modification of proteins by reactive aldehydes are believed to be involved in the inhibitory mechanism. The MDA levels and their agedependent increase observed in our study $(\sim 0.6-0.8$ $\mathrm{nmol} / \mathrm{mg}$ protein) were lower than those observed earlier ( 1.2-3.6 nmol/mg protein) (Cocco et al. 2005), possibly because instead of nonspecific TBARS method we used method for specific determination of free MDA. Both findings are, however, more than 2-3 orders lower than those inhibiting ETC complexes. Using isolated rat liver mitochondria Long et al. (2006) have shown that ETC complexes I and II are significantly inhibited by exogenous MDA from the concentrations of $800 \mathrm{nmol} / \mathrm{mg}$ protein and complexes III and IV were not inhibited even at $6.4 \mu \mathrm{mol} / \mathrm{mg}$ protein. Data on HNE content and its age-related changes in cardiac tissue are lacking. Our study shows that in adult hearts the HNE content is similar to MDA content but it increases more substantially with age; in 26-month old rats it was almost twice as big as in 6-month old rats. Several studies have shown that ETC complex activities were reduced when mitochondria were treated with 50-200 $\mu \mathrm{M}$ HNE (see Long et al. 2006), but few studies have demonstrated inhibition of enzymes and respiration at much lower concentrations (Chen et al. 1998, Humphries et al. 1998,
Kaplan et al. 2007b). Previously we have shown (Kaplan et al. 2007b) that complex IV activity is significantly inhibited when mitochondria were shortly exposed to $1 \mu \mathrm{M}$ HNE. This concentration corresponds to $2 \mathrm{nmol}$ $\mathrm{HNE} / \mathrm{mg}$ protein and is close to HNE level, which we found in aged hearts. The ability of HNE to affect mitochondrial proteins was confirmed by measurements of HNE-protein adducts. Our results are in agreement with previous studies showing only few HNE-modified proteins in cardiac mitochondria (Suh et al. 2003, Judge et al. 2005, Choksi and Papaconstantinou 2008). In addition, HNE adducts with low-molecular weight proteins did not increase progressively with age, but peaked in 15-month- and decreased back in 26-month-old rats. Similar profile for some proteins was observed by Choksi and Papaconstantinou (2008). In contrast to their study we have not identify HNE-modified proteins, therefore the effect of this modification on ETC is unknown. Nevertheless, observation that only few mitochondrial proteins showed age-dependent HNE modification suggests that this is not a common mechanism for inhibition of ETC complexes with age.

In conclusion, our study provides further evidence that aging results in non-uniform decline in activities of ETC complexes, which may be due, at least in part, to mitochondrial oxidative stress. Oxidative damage to ETC may occur directly by reaction with ROS or indirectly through LPO products, however, MDA and HNE appear to have a limited impact on enzyme functions. Further studies are needed to identify proteins subjected to oxidative modifications and the impact of these modifications on mitochondrial function.

\section{Conflict of Interest}

There is no conflict of interest.

\section{Acknowledgements}

This work was partially supported by grants VEGA 1/0027/08 and VVCE APVV 0064/07 from the Ministry of Education and Science of the Slovak Republic. We thank Ms. D. Durcova for technical assistance.

\section{References}

BABUSIKOVA E, KAPLAN P, LEHOTSKY J, JESENAK M, DOBROTA D: Oxidative modification of rat cardiac mitochondrial membranes and myofibrils by hydroxyl radicals. Gen Physiol Biophys 23: 327-335, 2004.

BARJA G: Mitochondrial oxygen radical generation and leak: sites of production in states 4 and 3, organ specificity, and relation to aging and longevity. J Bioenerg Biomembr 31: 347-366, 1999. 
CHEN J, SCHENKER S, FROSTO TA, HENDERSON GI: Inhibition of cytochrome-c oxidase activity by 4-hydroxynonenal (HNE). Role of HNE adduct formation with the enzyme subunits. Biochim Biophys Acta 1380: 336-344, 1998.

CHOKSI KB, PAPACONSTANTINOU J: Age-related alterations in oxidatively damaged proteins of mouse heart mitochondrial electron transport chain complexes. Free Radic Biol Med 44: 1795-1805, 2008.

COCCO T, SGOBBO P, CLEMENTE M, LOPRIORE B, GRATTAGLIANO I, Di PAOLA M, VILLANI G: Tissuespecific changes of mitochondrial functions in aged rats: effect of a long-term dietary treatment with N-acetylcysteine. Free Radic Biol Med 38: 796-805, 2005.

DAVIES SM, POLJAK A, DUNCAN MW, SMYTHE GA, MURPHY MP: Measurements of protein carbonyls, orthoand meta-tyrosine and oxidative phosphorylation complex activity in mitochondria from young and old rats. Free Radic Biol Med 31: 181-190, 2001.

ENDLICHER R, KŘIVÁKOVÁ P, RAUCHOVÁ H, NŮSKOVÁ H, ČERVINKOVÁ Z, DRAHOTA Z: Peroxidatve damage to mitochondrial respiration is substrate-dependent. Physiol Res 58: 685-692, 2009.

FANNIN SW, LESNEFSKY EJ, SLABE TJ, HASSAN MO, HOPPEL CL: Aging selectively decreases oxidative capacity in rat heart interfibrillar mitochondria. Arch Biochem Biophys 372: 399-407, 1999.

HANLEY PJ, RAY J, BRANDT U, DAUT J: Halothane, isoflurane and sevoflurane inhibit NADH:ubiquinone oxidoreductase (complex I) of cardiac mitochondria. J Physiol 544: 687-693, 2002.

HUMPHRIES KM, SZWEDA LI: Selective inactivation of $\alpha$-ketoglutarate dehydrogenase and pyruvate dehydrogenase: Reaction of lipoic acid with 4-hydroxy-2-nonenal. Biochemistry 37: 15835-15841, 1998.

JUDGE S, JANG YM, SMITH A, HAGEN T, LEEUWENBURGH C: Age-associated increases in oxidative stress and antioxidant enzyme activities in cardiac interfibrillar mitochondria: implications for the mitochondrial theory of aging. FASEB J 19: 419-421, 2005.

KANSKI J, BEHRING A, PELLING J, SCHÖNEICH C: Proteomic identification of 3-nitrotyrosine-containing rat cardiac proteins: effects of biological aging. Am J Physiol 288: H371-H381, 2005.

KAPLAN P, BABUSIKOVA E, LEHOTSKY J, DOBROTA D: Free radical-induced protein modification and inhibition of $\mathrm{Ca}^{2+}$-ATPase of cardiac sarcoplasmic reticulum. Mol Cell Biochem 248: 41-47, 2003.

KAPLAN P, JURKOVICOVA D, BABUSIKOVA E, HUDECOVA S, RACAY P, SIROVA M, LEHOTSKY J, DRGOVA A, DOBROTA D, KRIZANOVA O: Effect of aging on the expression of intracellular $\mathrm{Ca}^{2+}$ transport proteins in a rat heart. Mol Cell Biochem 301: 219-226, 2007.

KAPLAN P, TATARKOVA Z, RACAY P, LEHOTSKY J, PAVLIKOVA M, DOBROTA D: Oxidative modifications of cardiac mitochondria and inhibition of cytochrome c oxidase activity by 4-hydroxynonenal. Redox Report 12: 212-218, 2007.

KUMARAN, S, SUBATHRA M, BALU M, PANNEERSELVAM C: Age-associated decreased activities of mitochondrial electron transport chain complexes in heart and skeletal muscle: role of L-carnitine. Chem Biol Interact 30: 11-18, 2004.

KUMARAN S, SUBATHRA M, BALU M, PANNEERSELVAM C: Supplementation of L-carnitine improves mitochondrial enzymes in heart and skeletal muscle of aged rats. Exp Aging Res 31: 55-67, 2005.

KWONG LK, SOHAL RS: Age-related changes in activities of mitochondrial electron transport complexes in various tissues of the mouse. Arch Biochem Biophys 373: 16-22, 2000.

LEEUWENBURGH C, WAGNER P, HOLLOSZY JO, SOHAL RS, HEINECKE JW: Caloric restriction attenuates dityrosine cross-linking of cardiac and skeletal muscle proteins in aging mice. Arch Biochem Biophys 346: 7480, 1997.

LESNEFSKY EJ, HOPPEL CL: Cardiolipin as an oxidative target in cardiac mitochondria in the aged rat. Biochim Biophys Acta 1777: 1020-1027, 2008.

LONG J, WANG X, GAO H, LIU Z, LIU C, MIAO M, LIU J: Malonaldehyde acts as a mitochondrial toxin: Inhibitory effects on respiratory function and enzyme activities in isolated rat liver mitochondria. Life Sci 79: 1466-1472, 2006.

MIRÓ Ò, CASADEMONT J, CASALS E, PEREA M, URBANO-MÁRQUEZ Á, RUSTIN P, CARDELLACH F: Aging is associated with increased lipid peroxidation in human hearts, but not with mitochondrial respiratory chain enzyme defects. Cardiovasc Res 47: 624-631, 2000. 
MOHAMED SA, HANKE T, ERASMI AW, BECHTEL MJ, SCHARFSCHWERDT M, MEISSNER C, SIEVERS HH, GOSSLAU A: Mitochondrial DNA deletions and the aging heart. Exp Gerontol 41: 508-517, 2006.

NULTON-PERSSON AC, SZWEDA LI: Modulation of mitochondrial function by hydrogen peroxide. $J$ Biol Chem 276: 23357-23361, 2001.

PETROSILLO G, MATERA M, MORO N, RUGGIERO FM, PARADIES G: Mitochondrial complex I dysfunction in rat heart with aging: critical role of reactive oxygen species and cardiolipin. Free Radic Biol Med 46: 88-94, 2009.

PHANEUF S, LEEUWENBURGH C: Cytochrome $\mathrm{c}$ release from mitochondria in the aging heart: a possible mechanism for apoptosis with age. Am J Physiol 282: R423-R430, 2002.

POWELL CS, JACKSON RM: Mitochondrial complex I, aconitase, and succinate dehydrogenase during hypoxiareoxygenation: Modulation of enzyme activities by MnSOD. Am J Physiol 285: L189-L198, 2003.

PRESTON CC, OBERLIN AS, HOLMUHAMEDOV EL, GUPTA A, SAGAR S, SYED RH, SIDDIQUI SA, RAGHAVAKAIMAL S, TERZIC A, JAHANGIR A: Aging-induced alterations in gene transcripts and functional activity of mitochondrial oxidative phosphorylation complexes in the heart. Mech Ageing Dev 129: 304-312, 2008.

RACAY P, TATARKOVÁ Z, DRGOVÁ A, KAPLAN P, DOBROTA D: Ischemia-reperfusion induces inhibition of mitochondrial protein synthesis and cytochrome c oxidase activity in rat hippocampus. Physiol Res 58: 127138, 2009.

RODRÍGUEZ MI, CARRETERO M, ESCAMES G, LÓPEZ LC, MALDONADO MD, TAN DX, REITER RJ, ACUÑA-CASTROVIEJO D: Chronic melatonin treatment prevents age-dependent cardiac mitochondrial dysfunction in senescence-accelerated mice. Free Radic Res 41: 15-24, 2007.

SIVOŇOVÁ M, TATARKOVÁ Z, ĎURAČKOVÁ Z, DOBROTA D, LEHOTSKÝ J, MATÁKOVÁ T, KAPLÁN P: Relationship between antioxidant potential and oxidative damage to lipids, proteins and DNA inaged rats. Physiol Res 56: 757-764, 2007.

SUH JH, HEATH SH, HAGEN TM: Two subpopulations of mitochondria in the aging rat heart display heterogenous levels of oxidative stress. Free Radic Biol Med 35: 1064-1072, 2003.

YARIAN CS, REBRIN I, SOHAL RS: Aconitase is the main functional target of aging in the citric acid cycle of kidney mitochondria from mice. Mech Ageing Dev 127: 79-84, 2006.

ZHANG Y, MARCILLAT O, GIULIVI C, ERNSTER L, DAVIES KJA: The oxidative inactivation of mitochomdrial electron transport chain components and ATPase. J Biol Chem 265: 1630-1636, 1990. 